\title{
リトレッド工程と各技術について
}

\author{
中 根 慎 介
}

\section{Retread Process and Technology}

Shinsuke NAKANE(Commercial Tire Compound Development, Bridgestone Corporation, 3-1-1 Ogawahigashicho, Kodaira, Tokyo 187-8531, Japan)

Retread tire process can contribute to reduce $\mathrm{CO}_{2}$ reduction comparing to new tire manufacturing process as well as tire cost reduction for truck \& bus fleet's. Adhesion between cured rubber and uncured compound and casing durability are key performances for retread tire.

Key Words : Retread Tire, Remold Method, Pre-cure Method, Cashing Durability

\section{1. リトレッドの歴史と現状}

リトレッドタイヤとは使用したタイヤの残留トレッド部 を除去し，新たなトレッドを接合させて再使用するタイヤ のことで，主にトラック・バス用や航空機用タイヤに適用 されている。トレッド部のみの再生産であることから資源 の有効活用・リサイクルの一環として有効で，新品タイヤ 対比製造時，約 $60 \%$ の $\mathrm{CO}_{2}$ 発生量削減が可能である。（図 1）また世界的に長引く不況によりトラック業界では夕 イヤ費用の削減に向けて新品タイヤより安価なリトレッド タイヤを導入するケースが増えてきている．欧州・北南米 などのリトレッド普及率は既に我が国対比高く，中国でも 2015 年にトラック・バス用タイヤ全体に占めるリトレッ ド率を $25 \%$ ま゙引き上げる政府案が打ち出されているこ とから全世界的に今後もリトレッドが増えていくと予想で きる。リトレッドを普及させるには，再使用されるタイヤ の骨格部材の耐久性を確保することやカットなどのタイヤ 外傷も程度により修理することが必要となる。本稿ではリ トレッドタイヤの製造工程を紹介しながら関連するゴム技 術にも言及していきたい.

\section{2. リトレッド方式について}

リトレッド製造法として主流であるリモールド方式とプ レキュア方式を以下簡単に説明する（プレキュア方式の写 真はバンダグ式説明資料を使用する).

（1）リモールド（Remold）方式

トレッド部除去した使用済タイヤ(以下台タイヤと称す) にタイヤ1周分の未加硫ゴムトレッドを巻き，トレッドパ
ターン付モールドに入れて加硫する方法. トレッドの継ぎ 目が目立たず新品タイヤ同様なトレッド部の外観となり, 後述のプレキュア方式よりもこの点は良好である. トレッ ド押出・加硫工程などで用いる設備として新品夕イヤとほ ぼ同じ規模・仕様のものが必要となり, 大がかりな設備を 導入しなければならない。航空機用リトレッドは現在この 方法のみで生産されている.

（2）プレキュア（Pre-cure）方式

予め加硫しておいたトレッドを“組み立てる”ように使 用済台タイヤにクッションゴム（未加硫ゴム）を介して巻 き, 加硫缶と呼ばれる圧力容器に入れて加硫する方法. リ モールド方式のような大掛かりな加硫装置・熱源は一般的 には不要であることから，リモールド方式対比, 初期投資 が低額で済むため小規模りトレッダー（プレキュアトレッ ドを組み立てる工場）をすばやく広域に展開しやすい。加 硫缶加硫の温度・時間はクッションゴムの配合（加硫速度 など）により左右される.

グローバルにプレキュア方式を展開していることで著名 なBANDAGは全世界に 90 か国以上・800箇所以上にリト レッドショップを展開.プレキュアトレッドを販売するだ けでなく関連するリトレッド用設備・クッションゴム・製

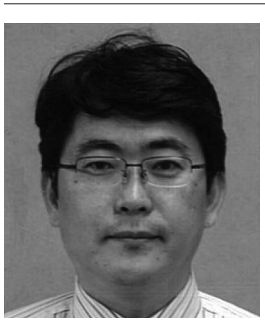

中根 慎介; 株)ブリヂストン 大型タイヤ材料 設計部（† 187-8531東京都小平市小川東町 31-1). 平成元年，大阪大学工学部卒業. 同年(株 ブリヂストン入社, 現在に至る。専門は, 夕 イヤ用ゴム配合の設計。 


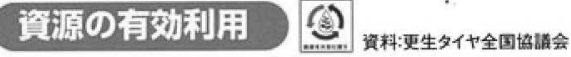

新品タイヤと比べて、製品製造に必要な

資源の量がわずか $32 \%$ す。

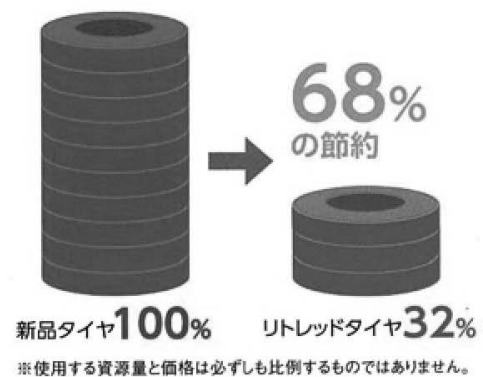

\section{$\mathrm{CO}_{2}$ 排出量剀腿 $\mathrm{CO}_{2}$}

製造過程·廃棄段階でCO $\mathrm{CO}_{2}$ を削隇します。

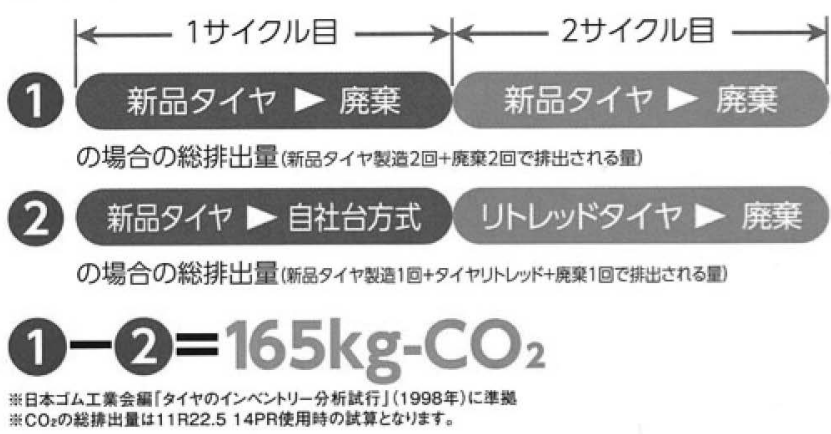

図1リトレッド適用による $\mathrm{CO}_{2}$ 削減見積もり ${ }^{1)}$

造法・規格を包括して提供し，品質を保ちながら幅広く展 開してきているのが特徴である。

\section{3. リトレッド工程とおさえるべき要素}

以下にプレキュア方式の主な工程写真などを用いて，各 工程でのゴム材料に求められる事項についても触れてみた い.

（1）台の受け入れ検査（リモールド・プレキュア方式共通） もう一度市場での走行が可能であるという視点での夕イ ヤ検査が必要となり，主には夕イヤ内部・外部に亀裂・空 隙などの損傷がないことを非破壊で行うチェックが適用さ れる。目視・手触りによる外観于ェック，通電による釘踏 みの検出，レーザー検查（シアログラフィー）による夕イ ヤ内部の空隙の検出などがある.

（2）バフ工程（リモールド・プレキュア方式共通：図2）

残ったトレッドを削りトレッド形状に合うように形を整 えることに加え，未加硫ゴムと台夕イヤの物理的接合面積 を増やすことがこの工程の目的．金属研磨の場合のバフは 表面を滑らかにするのが通常だが，リトレッドのバフは表 面を粗くすることが特徵. 台夕イヤに接する未加硫ゴムは, リモールド方式の場合はトレッドゴム，プレキュア方式の 場合はクッションゴムとなる。残存トレッド部を取り除く
ためにピーリングも取り入れる場合があるが，最終的には バフによって台タイヤの形が整えられる。バフ粗さについ てはRMA発行のStandard Buffing Textures Retreading and Repairingなども目視判定基準の参考となる ${ }^{2)}$ 。プレ キュア方式の場合はプレキュアトレッドの背面にもバフ処 理を施すことが十分な接着を得るために必要である.

（3）修理工程（リモールド・プレキュア方式共通）

釘踏みやトレッドカットによるスチールコード損傷など で腐食が見られる場合は，その部分を削り落とすスカイブ 処理（図3）を施し，その後に「修理ゴム・部修ゴム」な どと呼ばれる未加硫ゴムで穴埋めした後に，リモールドの 場合は加硫モールドに，プレキュアの場合は加硫缶に入れ て加硫接着させる，修理ゴムの必要な機能としてはスペー スを隙間なく埋めるために低粘度配合が適用されるが，ク ッションゴム同様の加硫ゴムとの接着性や周辺部材との剛 性段差が大きくなりすぎないように加硫後弾性率の考慮も 必要である。

（4）クッションゴムの配置（プレキュア方式のみ：図4）

リトレッドで最も重要な工程である未加硫ゴムと加硫ゴ ムの接着について，リモールド式では未加硫トレッドゴム が台タイヤと直接接着するためクッションゴムは通常不要

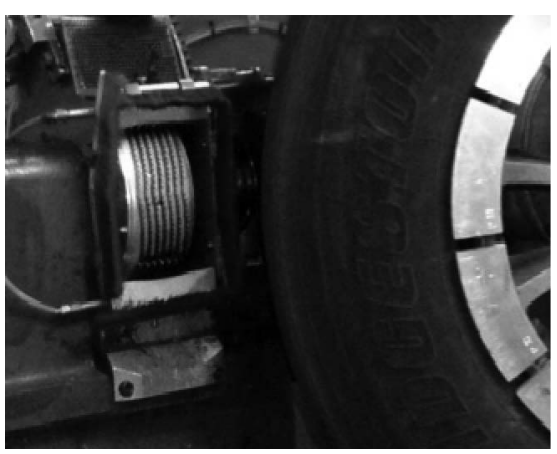

図2 バフ工程

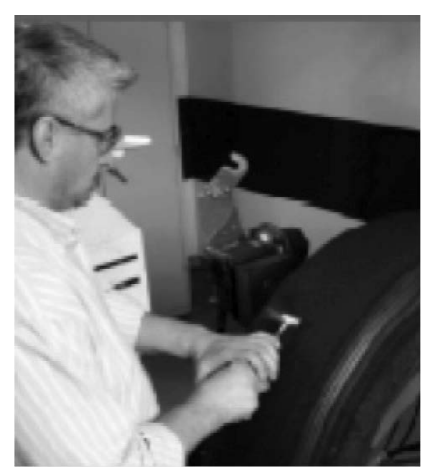

図3修理工程におけるスカイブ 
であるが，プレキュア方式の場合はトレッドと台タイヤが 両方加硫ゴムであるため, 接着の機能を持った未加硫ゴム クッションゴムが必要となる。このクッションゴムの機能 として

(1) 加硫前にプレキュアトレッドと台タイヤ表層の加硫 ゴムバフ面に隙間なく接触しうる粘度であること

(2) 通常, リモールド対比低い加硫缶温度で加硫反応し， 両側の加硫ゴム (プレキュアトレッドと台タイヤ表層) と架橋接着すること

(3) タイヤ入力に耐えうるクッションゴムそのものの破 壊強度

が求められる．前述の通り加硫缶での加硫温度などの条件 はこのクッションゴムの加硫速度・反応性に依存してい る。加硫缶での加硫中, 加硫熱と使用時にゴム中に拡散し ている酸素でゴム劣化が生じるとすると，加硫缶温度が低 いほど,加硫時間が短いほど再使用には好ましいと言える。

（5）加硫工程

リモールド方式の場合はトレッド部にパターン型あるモ ールドに入れ新品タイヤ製造に類似した加硫方式が用いら れる．プレキュア方式の場合はプレキュアトレッドを台夕
イヤのクッションゴムに巻くというプレキュアトレッド成 型（図5）を施した後にエンベロープ（図6）という加硫 ゴム外皮で覆うことでトレッド部を拘束し，加硫缶（図7） 内で一定の圧力と温度で加硫する。トレッドパターンの溝 幅が狭い場合などは溝底形状にエンベロープが接しない場 合があるため，溝底に圧力がかかりにくい，そのためエン ベロープ内も加圧し（但し加硫缶内圧よりは小さい），エ アで溝底を押さえる方法が適用される。

\section{4. リトレッド工程におけるコントロールすべき重要な技術}

\section{（1）未加硫ゴムと加硫ゴムの接着}

前述と重複するが，未加硫ゴムと加硫ゴムを接触させる 前にリモールド・プレキュアとも加硫ゴム側の表層をバフ 処理する効果は物理的接触面積増大（図 8) 以外にミクロ な現象（主鎖切断・架橋切断）も考えられ，加硫ゴムの状 態に合わせた「適度」なバフ処理が接着力を発現するのに 必要である。ラボサンプルでも加硫したサンプルをバフす ると剥離抗力が向上することから，バフ処理は接着力を向 上させる重要な工程と言える（パンクした自転車チューブ などもバフしてパッチを貼ることと共通).

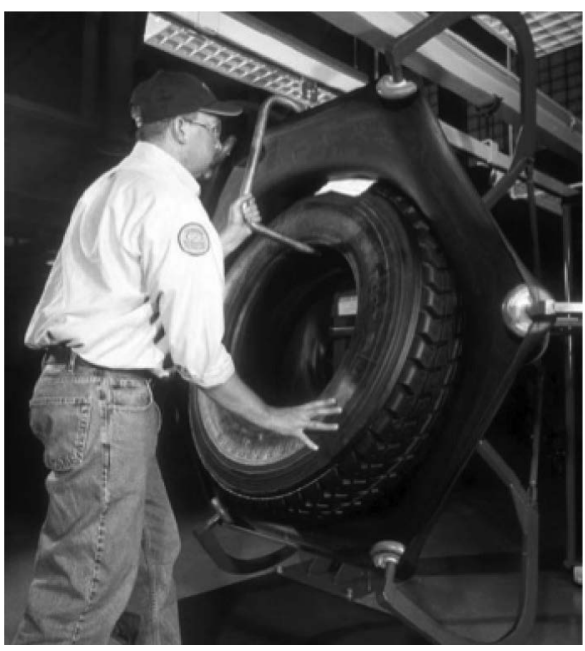

図6 エンベロープ（プレキュア方式のみ）

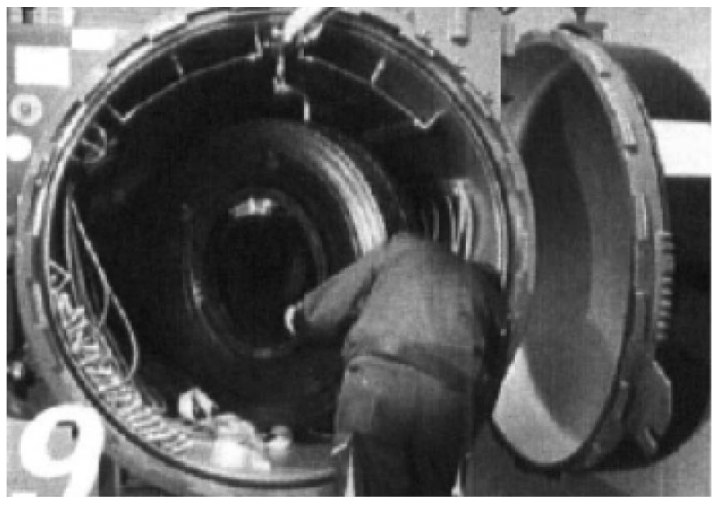

図7 加硫缶（プレキュア方式のみ） 


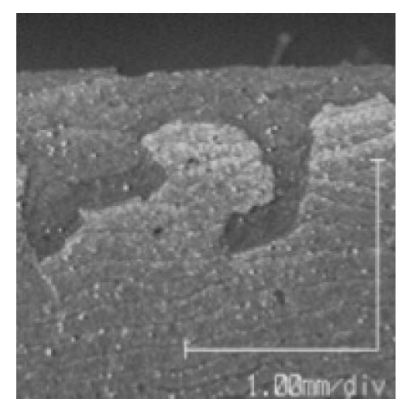

図8 バフ界面での加硫ゴムと未加硫ゴムの接触（写真はプレキュア の場合）

（2）リトレッド加硫条件

1 次使用を経てゴム劣化などがある程度進行したタイヤ に加硫熱をかけることになるため，リトレッド加硫条件は 加硫ゴムと未加硫ゴムの接着を確保した上で，低温・短時 間の方がタイヤ耐久性確保・加硫生産性のために望まし い.

\section{5. 結}

び

リトレッド技術として重要なのはいかに使用済台タイヤ をリトレッド加硫中に劣化させずトレッド部を台タイヤと 接合させるかである. リトレッドタイヤの売值が新品夕イ ヤ対比安価であるために導入できる製造設備や原材料に制 約がある中で, 効率的な製造法や製法に適したクッション 配合・トレッド配合の開発が必要になるであろう。

また普及に際しては使用済夕イヤを集める際に使用済夕 イヤが再使用に耐えうるかどうかを効率的に判断すること も必要になり，夕イヤ入力に対する残存耐久の予測技術が なおいっそう重要となる。

\section{Reference}

1) http://www.bridgestone.co.jp/csr/report/download/pdf/2003/ 06.pdf

2 ) http://www.rma.org/publications/tire_service_professionals/ index.cfm?PublicationID $=11052$

\section{日本語表記参考文献}

1) ブリヂストンCSRレポート 